\title{
Christian Advocacy Ministry in African Christianity: The Nature, Prospects and Challenges in Ghana
}

\author{
Kwabena Opuni-Frimpong 1 \\ 1 Department of Religious Studies, Kwame Nkrumah University of Science and Technology, Kumasi - Ghana.
}

\begin{abstract}
The contributions of the church to the social, economic and political growth of Ghana have been locally and internationally recognized. There is the need therefore, to subject the nature, prospects and challenges of the Christian advocacy of the church in Ghana to intellectual scrutiny to identify the issues that must be addressed for the church to perform its advocacy effectively. The study is an examination of the Christian advocacy ministry of the church in Ghana. It used both primary and secondary materials to generate data. Minutes and reports were examined for some primary information. The analysis of the available information points to the fact that the church must pay attention to niche management, capacity building of church leaders, enhance its public theology, creation of platforms for reflections, address the attacks on voices of wisdom, and direct attention to the role of the non-clergy in the advocacy ministry for its future Christian advocacy ministry. The study has added to knowledge in the disciplines of Church and Society and Public Theology.
\end{abstract}

Keywords: Advocacy Ministry, Public Theology, African Christianity, Capacity Building, Public Witness

(c) 2021 The Author. Published and Maintained by Noyam Publishers.

This is an open access article under the CCBY license (http://creativecommons.org/licenses/by/4.0/).

\section{INTRODUCTION}

The role of the church in the development of Ghana since its inception has been repeatedly acknowledged. Kudadjie and Aboagye-Mensah, ${ }^{1}$ Anquandah, ${ }^{2}$ Schweizer, ${ }^{3}$ Kwamena-Poh ${ }^{4}$ and Gifford ${ }^{5}$ have acknowledged the diverse contributions of the church to development through their various works. The contribution of the church to development has resulted due to the various ministries that the church has adopted over the years in its dealings with matters of governance and public policies.

Kudadjie has identified Christian advocacy as one of the ministries that the church in Ghana must pay attention to. According to him, the roles that ought to engage the attention of the church include the Prophetic i.e., speaking out clearly and unambiguously on important issues, warning, counselling, exhorting and commending as is necessary. Education i.e., creating awareness and realization in Ghanaian society of the dangers of lifestyles related to drug addiction, promiscuity, gambling, crude materialism etc. and Transformation i.e., working for the transformation of Ghanaian society through effective evangelization and social action,

1 Joshua.N. Kudadjie and R.K. Aboagye -Mensah Christian Social Ethics (Accra: Asempa Publishers, 1992).

2 James Anquandah, Agenda Extraordinaire: 80 years of the Christian Council of Ghana 1929-2009. (Accra: Asempa Publishers 2009).

3 Peter A. Schweizer Survivors on the Gold Coast. (Accra: Smartline Publishing 2000).

4 M.A. Kwamena-Poh Vision \& Achievement. (Accra: Waterville Publishing House, 2011).

5 Paul Gifford, Ghana's New Christianity: Pentecostalism in a Globalizing African Economy. (Indiana University Press, 2004). 
because society cannot really change unless the individuals in the society have changed. The Gospel of Jesus Christ and the transforming power of the Holy Spirit are by far the most potent agents of transformation, and the church has them as well as the role of Advocacy. ${ }^{6}$ Kudadjie subsequently explained Advocacy as, 'serving as watchdog and conscience of the nation, pointing out abuses, protecting and defending the rights of all: humans, animals and the entire environment. It must be the Advocate for the voiceless to bring improvement and progress.' ${ }^{7}$

The individual churches and the ecumenical bodies have subsequently played various roles in advocacy ministries in Ghana. ${ }^{8}$ The Christian Council of Ghana, for instance, has remained a very leading role in the Christian advocacy ministry in Ghana. When the Christian Council of Ghana was founded in 1929 the broad aims of the founding members were that of the pursuit of, ecumenism and advocacy. Specifically, they set themselves to "search for unity, to work with member churches on issues of social concern and to be the voice of the voiceless in society."

Walls ${ }^{10}$ and Bediako ${ }^{11}$ have acknowledged the massive growth of African Christianity. According to Walls, the center of gravity of global Christianity has shifted to the global South. Ghana like other African countries has witnessed massive Christian growth. In spite of the different persuasions, it can be said that, Ghana still remains a predominantly Christian country.

The country that has witnessed massive Christian growth has also experienced massive socio-economic challenges. The challenges of unemployment of young people, disease, illiteracy, corruption and economic challenges have also remained with Ghanaians. ${ }^{12}$ In the midst of these challenges, there is an expectation that the advocacy ministry of the church will become more visible and eminent.

Adarkwa in a Strategic Plan that he presented to the Christian Council of Ghana in 2014 insisted that the Christian Council of Ghana is still relevant. He noted that, 'it must be re-echoed that the Christian Council of Ghana is still very relevant and adequately prepared for these times. ${ }^{13}$ He however, pointed out that the Christian Council of Ghana's relevance must be identified in its maintenance of the initial vision of the founding fathers.

Adarkwa has subsequently admonished that in order to maintain their relevance, the churches must continue to focus on their core mandate as envisaged by the founding fathers which are that of ecumenism and advocacy. Moreover, there is the need for the church to expand its advocacy ministry as it seeks to be relevant in the current situation of the country. Adarkwa therefore recommends a further expansion in the advocacy ministry of the church. Even though he acknowledges the progress that the church has made over the years, he points out that, "there is room however for further expansion. ${ }^{14}$ The study seeks to examine the nature, prospects and challenges of the Christian advocacy ministry of the church in Ghana and the issues that must be addressed for a more effective and eminent service.

\section{METHODOLOGY}

The study is a library focused one. As qualitative in nature, it examines available primary and secondary materials on the subject of the nature, prospects and challenges of Christian advocacy ministry in African Christianity specifically focusing on the Ghana church. An analysis is subsequently done on the available information to ascertain lessons for the church in pursuit of the advocacy ministry. Specific attention is given to reports, minutes and strategic plans of the Christian Council of Ghana as the oldest ecumenical body and a leading voice in Christian advocacy in Ghana.

\footnotetext{
6 Anquandah, Agenda Extraordinaire: 80 years of the Christian Council of Ghana 1929-2009., 35.

Anquandah,. Agenda Extraordinaire: 80 years of the Christian Council of Ghana 1929-2009. 35.

8 R.E. Gyampo, The Church and Ghana's Drive Towards Democratic Consolidation and Maturity. Journal of Political Science Pub Aff3:161. (2015).

9 Christian Council of Ghana Strategic Plan 2014-2024, April 2024.

10 Andrew Walls, The Missionary Movement in Christian History. (New York: Orbis Books, 1996).

${ }^{11}$ Kwame Bediako, Theology and Identity: The Impact of Culture Upon Christian Thought in the Second Century and Modern Africa, (Oxford: Regnum Books 1992).

12 Joesph R.A. Ayee, Leadership and the Ghanaian State Today: Reflections and Perspectives. (Accra: Checkpoint, 2017).

13 Kwasi Kwafo Adarkwa,. Report on Christian Council of Ghana Strategic Plan 2014-2024..

14 Adarkwa. Report on Christian Council of Ghana Strategic Plan 2014-2024.
} 


\section{CHRISTIAN ADVOCACY}

Advocacy is serving as watchdog and conscience of the nation, pointing out abuses, protecting and defending the rights of all: humans, animals and the entire environment. It must be the advocacy for the unheard voices to bring improvement and progress. ${ }^{15}$ Christian advocacy is pleading the cause of another, siding with, vindicating, pleading and making recommendations on behalf of others with the Christian values and perspectives. Moreover, advocacy is the giving of private or public support to a person, an idea, institution, a course of action, or a belief system. ${ }^{16}$

Ideas that affect both individuals and groups of individuals must be given support in areas such as justice, human rights, human dignity, good governance, road safety, environment,etc. Furthermore, the strengthening of public institutions must attract the support of the church in areas such as education, health, security, trade, health insurance, mining, chieftaincy and taxation. Christian issues such as religious persecution, religious freedom, ministerial integrity, discipleship, renewal of faith, missionary expansion, evangelism, salvation, Christian giving, media relations, music and theological education must remain on the agenda of Christian advocacy. ${ }^{17}$

Christian advocacy moreover, has been identified by $\mathrm{Kim}^{18}$ and $\mathrm{Kare}^{19}$ as an action by the church and its members which aims to influence public-policy and resource allocation decisions within political, economic, and social systems and institutions. It may include many activities that the church undertakes including media campaigns, public speaking, commissioning and publishing research polls, the filing of an amicus brief, peaceful demonstrations etc. It must be noted that some disadvantaged in society may never get help and interventions if the abled individuals and groups do not provide support.

It must be noted that the strength of a society is determined among others by how the abled in the society are prepared to enable the disabled. Advocacy must be pursued by the abled in society through public education, engagement with state institutions, dialogue, contribution and participation in public discourses, identification of issues, consultation, condemnation or naming and shaming.

Advocacy has remained one of the gifts that God has used to demonstrate his love, care, sovereignty, power and justice since creation. Perpetuation of sin, suffering, and injustice have become possible only when advocacy is truncated and abused. While many individuals that have been called into the ministry of advocacy have not given a serious response to that dimension of Christianity, others have abused the privileges of advocacy. However, God has used individuals and groups to challenge and change the cause of history through advocacy.

\section{Christian Advocacy as Public Witness}

Christian public witness takes its roots from the Bible and theology. Gutierrez has noted that, "the Bible is the book of the promise, the promise made by God to human beings, the efficacious revelation of God's love and self-communication; simultaneously it reveals humankind to itself. ${ }^{20}$ The church takes its mandate and example in offering faith perspectives on public matters from the scriptures that bring God's promises and hope.

The Bible provides examples of individuals and passages that motivate involvement in public witness. The scriptures facilitate individual and social transformation. According to Stott, 'evangelism is the major instrument of social change. The gospel changes people, and changed people can change society. ${ }^{21}$ Christian public witness is the effort to bring faith perspectives and values on public issues with the intention to effect social change and transformation.

Christian public witness brings the church to the model of the ministry of Christ. Jesus offered the power of the gospel to meet both the physical and spiritual needs of the people. He invited his hearers to the kingdom of God as well as responded to their other needs. 'And Jesus went about all Galilee, teaching in

\footnotetext{
${ }_{15}$ Anquandah. Agenda Extraordinaire: 80 years of the Christian Council of Ghana 1929-2009.

${ }_{16}$ Kwabena Opuni-Frimpong, Christian Ministry of Advocacy. (Accra: Sonlife Press 2015).

17 Opuni-Frimpong. Christian Ministry of Advocacy, 78.

18 Sebastian Kim, Theology in the Public Sphere: Public Theology as a Catalyst for Open Debate. (London: SCM Press 2011).

19 Karel T. August. The Quest for Being Public Church, The South African Challenge to the Moravian Church in Context 17372004. (Bellville: The Print-Man 2009).

${ }^{20}$ Gustavo Gutierrez A Theology of Liberation. (New York: Orbis Books 1988), 91.

${ }^{21}$ John Stott, Issues Facing Christianity Today. (London: Marshall Pickering 2006), 7.
} 
their synagogues, and preaching the gospel of the kingdom,' (Matt 4:23, 9:35 KJV). He also responded to the material needs by offering healing to the sick. 'How God anointed Jesus of Nazareth with the Holy Ghost and with power: who went about doing good, and healing all that were oppressed of the devil; for God was with him' (Acts 10:38 KJV).

Christian public witness invites the church to participate in both evangelism and social responsibilities. Stott has opined that the church should never separate evangelism from social responsibilities. The separation of evangelism and social responsibilities according to him is a strange thing for the church to do. ${ }^{22}$ The paradigm of Jesus's public ministry must always guide the church to keep the balance. Stott has therefore opined that, 'evangelism and social concern have been intimately related to one another throughout the history of the church. Christian people have often engaged in both activities quite unselfconsciously, without feeling any need to define what they were doing or why. ${ }^{23}$

The church is a community of hope. The hope that the church offers however, must not be limited to its members. Tveit, ${ }^{24}$ has opined that, "if it is not a hope for all, it is not a real hope, and it is not a Christian hope. A necessary condition for hope is that it expresses itself in love for others, whoever and wherever they are. ${ }^{25}$ The church therefore is and must be seen at all times by its members and non-members as an institution of hope in moments of despair as its ministry of advocacy and public witness.

The church's effort in public witness and advocacy must be guided and rooted in scripture and sound Christian theology without reducing the Christian message of hope to any social theory and developmental goals. According to Tveit, 'Christian faith in the public space must remain confidence and trust in God, in the content of Christian doctrine, in the teaching of Christian traditions, in a commitment to serve and share, in embodying a community of faith and practice, in common witness in words and deeds. ${ }^{26}$

\section{Some Biblical Basis for Christian Advocacy}

In his discussion of the spiritual gifts, the Apostle Paul noted the gift of help. "And God has placed in the church first of all apostles, second prophets, third teachers, then miracles, then gifts of healing, of helping, of guidance, and of different kinds of tongues' (1 Cor 12:28 KJV). The gift of helping enables the church to pursue Christian advocacy both to church members as well as the bigger society. It enables to church to offer help with compassion, mercy and empathy to society without expectation of any direct benefits. To the church in Galatia Paul instructed, 'carry each other's burdens, and in this way, you will fulfill the law of Christ' (Gal.6:2 KJV).

Fulness and meaningful life relate much to matters of human dignity. Jesus promises fulness and abundant life. 'The thief comes only to steal and kill and destroy; I have come that they may have life, and have it to the full' (Jn 10:10 NIV). Human dignity and fulness of life respond to the provision of food to the hungry, healing to the sick, and security to the unsecured. The fulness of life is expressed in terms of meeting the basic needs of life that make life meaningful. Poverty, disease, unemployment, civil wars, hunger are considered detriments of life. The church, therefore, contributes to the fullness of life by supporting policies that support social interventions and are pro-poor.

Christians have been considered as the light and salt of the world. The position of the church in society indicates that the church must bring some positive impacts on society. 'You are the light of the world. A town built on a hill cannot be hidden. Neither do people light a lamp and put it under a bowl. Instead, they put it on its stand, and it gives light to everyone in the house. In the same way, let your light shine before others, that they may see your good deeds and glorify your Father in heaven' (Matt 5:14-16 NIV). According to Stott, 'the world is dark, Jesus implied but you (Christians) are to be its light. The world is decaying, but you are to be its salt and hinder its decay. ${ }^{27}$ The church is needed to bring influence on society as it reflects the light of Christ on public issues.

\footnotetext{
22 Stott. Issues Facing Christianity Today, 2.

23 Stott. Issues Facing Christianity Today, 2.

24 Olav Fykse Tveit The Role of Religion in Sustainable Development and Peace. (Berlin World Council of Churches. February 17-18, 2016).

25 Tveit, The Role of Religion in Sustainable Development and Peace.

${ }_{26}$ Tveit, The Role of Religion in Sustainable Development and Peace.

27 Stott. Issues Facing Christianity Today, 66.
} 
The church and its members are considered as God's instrument of change and transformation. It takes the people who have encountered the grace and mercy of God to become the instruments of divine grace and mercy. The Lord in the Book of Ezekiel indicated, 'I looked for anyone to repair the wall and stand in the gap for me on behalf of the land, so I wouldn't have to destroy it. But I couldn't find anyone' (Eze 22:30 NIV). It is when the church accepts to stand in the gap for the sake of the nation that the wounded society receives hope and help from God.

The church's participation in the peace and prosperity of the nation is for its own good. The church is to seek the peace and prosperity of the nation for it is in its peace and prosperity that the church and its members will enjoy their peace and prosperity. 'Also, seek the peace and prosperity of the city to which I have carried you into exile. Pray to the Lord for it, because if it prospers, you too will prosper' (Jer. 29:7 NIV). The concern of the church in public issues stems from the fact that the church can not just look on when society is going through sustainable destruction and danger. The hurt in the society consequently becomes the church's pain as well.

Christians are called to make intercessions on behalf of others. 'If my people, which are called by my name, shall humble themselves, and pray, and seek my face, and turn from their wicked ways; then will I hear from heaven, and will forgive their sin, and will heal their land' (2 Chr. 7:14 KJV). The world that can be sick of sin, suffering and injustice must have the church with the prophetic voice to confront the world in its sinfulness and also to bring it to God's love, hope and comfort. There is a divine call for the church to make interventions for the nation. Due to their relationship with the Lord, he will hear their intercessions.

\section{Historical Perspectives on Christian Advocacy}

Western missionaries who worked in different parts of Ghana came primarily to spread the gospel. The Christian understanding of the missionaries however, indicated that the gospel demands participation in the process towards the well-being of the recipients of the gospel. In the various mission stations, issues of education, health, agriculture, industry and quality of life remained on the agenda of missionaries. While they pursued some of such developmental projects on their own, Debrunner ${ }^{28}$ and Kwamena-Poh ${ }^{29}$ have indicated that they also partnered with the colonial authorities and their parent missionary bodies to meet the human needs of the people that they have come to share the gospel with.

The interest of the missionaries in matters of public concern was connected to their theological underpinnings of missions. According to Schweizer ${ }^{30}$ and Smith, ${ }^{31}$ the Zwinglian understanding of ora et labora (pray and work) served as the theological and ethical basis for missionary work of the Basel Mission. ${ }^{32}$ The churches established by such missionary bodies have therefore never ceased to participate in public issues from the missionary era, before, during and after independence.

The church's Christian advocacy has been very paramount in good governance and human rights. The ecumenical bodies resisted the Preventive Detention Act of Kwame Nkrumah's regime. Even though Nkrumah did not attach much seriousness to the request of the church, the Preventive Detention Act has eventually been expunged from the law books of Ghana. ${ }^{33}$

The Christian advocacy of the church has been extended to the struggle towards independence and democratic consolidation of Ghana. The frequent military interference in governance did not help the democratic system of governance. The joint advocacy of the ecumenical bodies like the Christian Council of Ghana, Ghana Catholic Bishops Conference, and the Ghana Pentecostal and Charismatic Churches eventually made a significant contribution towards the return to civilian rule. The PNDC constituted the consultative assembly that drafted the constitution for the fourth Republic. The membership included representatives from the various ecumenical bodies. ${ }^{34}$ The Christian Council of Ghana has sustained its regular issuance

\footnotetext{
${ }^{28}$ Hans W Debrunner. A History of Christianity in Ghana. (Accra: Waterville Publishing House 1967).

${ }^{29}$ Kwamena-Poh M. A. Vision \& Achievement.

30 Schweizer. Survivors on the Gold Coast, 93.

31 Noel, Smith. The Presbytery Church of Ghana 1835-1960 (Accra: Ghana Universities Press 1966).

32 Schweizer. Survivors on the Gold Coast, 93.

${ }^{33}$ Anquandah. Agenda Extraordinaire: 80 years of the Christian Council of Ghana 1929-2009, 115

${ }^{34}$ Anquandah. Agenda Extraordinaire: 80 years of the Christian Council of Ghana 1929-2009, 115
} 
of communiques ${ }^{35}$ and the practice of issuance of joint communiques with the Ghana Catholic Bishops Conference $^{36}$ and the Ghana Pentecostal and Charismatic Churches ${ }^{37}$ as part of its Christian public witness.

The Presbyterian Church of Ghana at its $65^{\text {th }}$ Synod held at Kyebi in 1994 deliberately took a decision to present a communique to the people and governments of Ghana. The rationale of the decision was to broaden its influence on the public witness, the shaping of public opinion of the citizens and the governance of the nation. ${ }^{38}$ The church has subsequently tasked its Church and Society committee under the Ecumenical and Social Department to annually present a draft communique for the general reflections at the General Assembly. The task has been spelt out in the church's Manual of $\operatorname{Order}^{39}$ and has kept the practice of issuance of communiques as part of its public witness. ${ }^{40}$

\section{Advocacy as Holistic Christian Ministry}

Christian mission is holistic. ${ }^{41}$ The holistic approach is instinctive. The holistic mission of the church relates well with traditional African spirituality that holds the belief that religion and life are inseparable. ${ }^{42}$ This provides an insight into spirituality which the Gospel teaches clearly that is also at home with African Christians.

The Gospel must respond to the realities of the context within which it serves. ${ }^{43}$ For example, Jesus' teaching on God as Father in the African context, calls people to trust God as the provider of their needs while they engage themselves in his service. At the same time, it challenges the church to prove the reality of God by demonstrating his power to provide material needs in the context of the power struggle among the spiritual forces which dominate religious consciousness. Within Africa, people are especially aware that there is no choice between witnessing to the living God in words and actions. There is a religious dimension to every aspect of life which means that actions and events reveal the presence of God. Christians' practical love is in itself an expression of the fatherhood of God.

\section{The Prospects}

The church as an organization is perceived as credible, recognized and respected by the public and governments in Ghana. Working relationships with governments are amicable and contribute to mutual trust and confidence making it possible for critical solidarity. The church has apparently carved for itself as a national image with clear legitimacy due to a constituency that is wide and extensive including a lot of infrastructure. Besides, the church is strategically positioned as a voice for the unheard voices and a reference point for the public, on public policy politically, socially, economically and religiously. Additionally, as a representative voice of member churches on issues of injustice and poverty the ecumenical bodies like the Christian Council of Ghana, is able to develop consensus among churches on the issues. The ecumenical bodies take lead on national issues, for instance, involvement in the democratisation process by creating awareness through voter and civic education.

The church in Ghana has built a niche of credibility and goodwill for its Christian public witness. ${ }^{44}$ The church is not only respected but also trusted by governments and the public of Ghana. Donor agencies, civil society organizations and traditional leaders relate with the church with respect and a sense of goodwill.

\footnotetext{
${ }^{35}$ Communique on National issues by the Christian Council of Ghana adopted at the Joint Heads of Churches/Organizations and Executive Committee Meeting of the Christian Council of Ghana held at its Secretariat on December 17, 2013

36 Joint Press Statement by the Christian Council of Ghana and the Ghana Catholic Bishops' Conference Issued in Accra on May $18,2016$.

37 Joint communique of the Christian Council of Ghana and the Ghana Pentecostal and Charismatic Council, issued in Accra on June 8, 2016.

${ }^{38}$ J. O. Y. Mante and D. Aboagye-Dankwa. Presbyterian Church of Ghana, Synod Decisions and the Rationale behind the decisions (1975-200), (Accra: Adwinsa Publications, 2014).

39 Presbyterian Church of Ghana, Manual of Order. (Accra: Waterville Publishing House, 2017).

40 Communique issued by the Presbyterian Church of Ghana (PCG) at the end of its $19^{\text {th }}$ General Assembly at Abetifi-Kwahu in the Eastern Region of Ghana from $16^{\text {th }}-22^{\text {nd }}$ August, 2019.

${ }^{41}$ Emmanuel Asante. Theology and Society in Context: A Theologist's Reflections on Selected Topics. (Accra: Sonlife Press, 2014).

42 Robert S. Rattray, Religion and Art in Ashanti. (London: Oxford University Press, 1927).

43 Asante. Theology and Society in Context: A Theologist's Reflections on Selected Topics.

${ }_{44}$ Agnes R.M. Abuom,. Report of Christian Council of Ghana on Organization Development Assessment July, 2005.
} 
The acceptance of international donor agencies like the UNHCR, WHO, USAID etc. to provide funds for the programmes and projects of the churches and ecumenical bodies deepen the public trust in the church. The church has come to be considered as an institution of trust in moments of elections, a threat to peace and violence. The credibility and goodwill that the church enjoys grant access to and the opportunity to influence decision makers in the state and church arena.

Abuam has however, called for proper management of the niche of the church. Using the Christian Council of Ghana as a case, she argued that, 'there is need for the Council to improve its niche management.' ${ }^{45}$ Niche development and profiling should emanate from a clearly defined vision, mission and core business. Individual churches and ecumenical bodies have not considered Christian public witness as a core ministry. Adarkwa has considered the church's participation in national issues as reactionary. They come only when there are issues in the public domain. The church does not have regular staff and ministers whose function is to regularly study and provide information on websites, public media, and the development of public relations materials. ${ }^{46}$

The church's advocacy ministry is strengthened by its spread in every part of the country. Churches are spread in almost every community. Moreover, the organization of the churches around the Local Council of Churches facilitates the unity of the faith community. The Local Council of Churches and the churches in the communities, however, have not considered their roles in the advocacy ministry as they look up to their various national head offices to handle matters of public issues. This grass-root entity at the local level enables the church to have a representation in almost every nook and cranny of the country. It is an invaluable tool when mobilizing grass root support.

The church and the ecumenical bodies have a good track record having undertaken quality programmes that according to Essah ${ }^{47}$ and Yeboah $^{48}$ fit the national vision that has yielded results in health, education, agriculture, HIV/AIDS, interfaith harmony, good governance, support for needy people, relief and rehabilitation over the years.

The individual churches and ecumenical bodies have accomplished much using their meagre resources generated mainly from their membership. Voluntarism provides added capacity for the church to strengthen the capacities of its members. Individual professionals are willing and do make their varied expertise available to the church without commensurate cost. The voices of the non-clergy are however not heard in Christian advocacy of the church.

Ghana has under the $4^{\text {th }}$ Republic enjoyed relatively peaceful and stable democratic governance. According to Gyimah-Boadi, Ghana's present situation offers several positive lessons for African democratization and nation building in the new century. ${ }^{49}$ The peaceful and democratic environment has facilitated rule of law, freedom of speech and vibrant media. The church has been able to participate in constructive dialogue and advocacy due to the enhanced environment.

The church and the ecumenical bodies are seen as mainly being non-partisan in their advocacy role on national issues. The non-partisanship is as a result of the fact that the church is not committed to any particular political party. Church members are free to identify with political parties of their choice but the parent church is not allowed to do so per their own individual constitutions. There have however, been constant attacks against the church and its leadership on partisanship depending on what the church says and at what moment. The perceptions that emanate from the camp of the major political parties on the church and ecumenical bodies of being partisan do not enhance the role of the church as an honest broker.

\section{The Challenges}

The Christian Council of Ghana, the oldest ecumenical movement in Ghana, has over the years harnessed the strength of its member churches in providing responses to public concerns. The Council has consequently

45 Abuom, Report of Christian Council of Ghana on Organization Development Assessment July, 2005.

46 Adarkwa. Report on Christian Council of Ghana Strategic Plan 2014-2024, April 2024.

${ }^{47}$ Kwame AS. Essah, Address presented as the Resident Advisor of Family Health International on the occasion of HIV/AIDS programme launch by the Presbyterian Church of Ghana at the Covenant Congregation Dzorwulu on Friday February $23,2001$.

48 Kwaku Yeboah,. Address presented as the Programme Manager, National AIDS Control Programme on the occasion of HIV/ AIDS programme Launch by the Presbyterian Church of Ghana at the Covenant Congregation Dzorwulu on Friday February 23, 2001.

49 E. Gyima-Boadi, CDD-Ghana Briefing Paper Volume 8, Number 4. January 2008. 
gained respect both locally and internationally for its advocacy ministry. It must however, be noted that the atmosphere gradually is changing. Formerly when the Christian Council of Ghana spoke on national issues it was accepted as representing the majority of Christians in the nation. With the upsurge of other institutions e.g. the Ghana Pentecostal Council, the National Association of Charismatic Churches and the many African Independent Churches, that role is being called to question.

The church's front is been represented by other voices. The current religious landscape has become cluttered with many groups and movements. Some of the more traditional roles of promoting unity that hitherto was being played by the Christian Council of Ghana have been encroached upon by some of these newer movements. The Ghana Pentecostal Council and the National Council of Charismatic Churches are now fostering unity among a section of churches.

The original niche of the church has been weakened because each member church and other ecumenical bodies are doing what the Christian Council of Ghana did before. The varied voices have come with varied opinions and positions on public issues sometimes with conflicting views from the church. The phenomenon has the tendency of weakening the advocacy of the church. It provides the platform for politicians to align with the voice that suits them and therefore eventually turn the church against itself due to its public divisions on national issues.

The bulk of the church's advocacy programmes especially the ecumenical bodies are donor-driven and thus their sustainability remains a very major challenge. Unless alternative sources of funding are secured, whenever the donors decide to pull out, signals the demise of various programmes including advocacy programmes being undertaken with donor funding. When the country was designated as a lower-middleincome country, a good percentage of donor assistance was cut off and channeled elsewhere. The donor dependency of the church's advocacy is a weakness that must be addressed. This puts the sustainability of these programmes at the mercy of the donors.

There is a perception that the ecumenical bodies and other church leaders should commit to advocacy on behalf of the citizens for good governance, accountability, human rights and national interests. The issue that keeps confronting the church leaders remains the capacity building for the task. The specialized area that has come to be considered as public theology ${ }^{50}$ needs bigger concentration at the seminaries that train pastors in and run regular programmes to build the capacity of the church for the advocacy ministry as pertains in other sectors of the church to remain functional in realizing its advocacy mandate.

\section{Some Lessons and Recommendations}

Some lessons learnt from the study include, niche management, capacity building of church leaders, enhancing public theology, creation of platforms for reflections, attacks on voices of wisdom, and the attention to the role of the non-clergy in the advocacy ministry.

\section{Niche Management}

The church in Ghana has a very strong niche of goodwill and credibility for its Christian advocacy. The niche however, must be properly managed. The participation over the years has been as and when there is a public cry for intervention. There has not been consistent, regular and systematic Christian advocacy on public concerns. Moreover, the ecumenical bodies that have the semblance of consistent advocacy have remained donor-driven.

The church may need to reconsider the human and logistics mobilization for its Christian advocacy for optimum utilization of its current niche. The niche management will respond to the impression of advocacy as a byproduct of an afterthought. There is the need to put in place departments that gather and process information and interface with the public. A review of the working relationships both vertically and horizontally will help optimize staff strength and help the church to be more functional in realizing its Christian advocacy mandate.

\section{Capacity Building of Church Leaders}

The effort of achieving effectiveness and efficiency in other sectors of Christian ministry explains the constant training of church leaders. The advocacy ministry equally must attract systematic effort on capacity building of church leaders to function effectively in that assignment as well. According to Ayee, 'leadership at all levels

50 Kim,. Theology in the Public Sphere: Public Theology as a Catalyst for Open Debate, 3-5. 
has increasingly been singled out as the most important variable that has shaped the various developments and governance outcomes witnessed on the African continent. ${ }^{51}$ Faith perspectives must be done for the common good and the glory of God. The church must save its image from public ridicule and disgrace. 'How beautiful are the feet of those who bring good news!' (Roms. 10:15). Those who are sent to Christian advocacy must be well prepared for a very effective and efficient service.

\section{Enhancing Public Theology}

The theology that is informing the faith perspectives on public issues needs reflection for clear mobilization, coordination and some clearance. The mainline churches usually consider public policy matters as decisions by governments and therefore adopt constructive dialogue with governments and policymakers while they continue in prayers for the state, its people and leaders. Gifford has argued that the approach of the Pentecostals, Prophetic and Charismatic groups seem to spiritualize public issues. He has subsequently opined that the national challenges are perceived to be caused by demons, satanic powers, and evil spirits. ${ }^{52}$ The search for deliverance, spiritual directions, divine prosperity and deeper anointing have become the major approach to public concerns. Prayer remains the major key as the strong national prophets and gatekeepers remain truthful to their assignments. Effective Christian advocacy ministry in Ghana demands some clarity and common grounds to save the church from public division and ridicule.

\section{Platforms for Reflections}

The preparedness of the individual churches and different ecumenical bodies to work together definitely will make significant contributions to the advocacy ministry of the church. The seeming division of opinions in the public space by the church must be addressed by strengthening the platforms of engagements and reflections to share best practices and information. As long as they remain on their own without dialogue and engagements, the divisions on opinion will remain and eventually will not be beneficial to the advocacy ministry.

\section{Attacks on Voices of Wisdom}

The Christian advocacy ministry in Ghana has attracted varied responses. While on several occasions the church has received commendations for its role in the national good there are instances of attacks on the church. Asante, ${ }^{53}$ Anquandah, ${ }^{54}$ and Gyampo ${ }^{55}$ have considered the attacks as efforts to silence the voices of wisdom emanating from the faith community. The phenomenon was witnessed under the Kwame Nkrumah regime and has not ceased. Asante has considered the attacks on the church's voice by governments and their dedicated foot soldiers as 'unfair'. According to Asante, 'it is unfair when religious leaders and organizations are vilified for stating their opinions on issues of national concern. ${ }^{56} \mathrm{He}$ has further considered the approach as a deliberate effort of successive governments just to silence the voice of wisdom coming from the church. Church leaders must constantly be aware of the practice and get themselves ready for it. Moreover, the issue must be brought to governments and political party leaders in some of the regular church and state engagements for discussion.

\section{The Role of the Non-Clergy}

The Christian advocacy ministry has been mainly clergy focused without much involvement of the nonclergy. The church is blessed with a laity with varied strong professional backgrounds that must be enhanced for the public witness. The laity have not been much committed to the public witness of the church maybe because they have not been committed to doing so. The expectation on Christian advocacy has always been towards the clergy and even specifically on the national leadership and the ecumenical bodies. The Christian advocacy ministry of the church may not achieve much if laypeople are not involved in the public witness

\footnotetext{
51 Ayee. Leadership and the Ghanaian State Today: Reflections and Perspectives, vi.

52 Gifford. Ghana's New Christianity.

53 Asante. Theology and Society in Context: A Theologist's Reflections on Selected Topics.

54 Anquandah. Agenda Extraordinaire: 80 years of the Christian Council of Ghana 1929-2009.

55 Gyampo, The Church and Ghana's Drive Towards Democratic Consolidation and Maturity, 161.

56 Asante. Theology and Society in Context: A Theologist's Reflections on Selected Topics.
} 
on good governance, human rights, accountability, public service, justice and peace in spite of efforts by the clergy.

\section{CONCLUSION}

The examination of the Christian advocacy ministry of the church in Ghana has pointed out the significant contributions of the church to the social, economic and political development of Ghana. The nature, prospects and challenges of the Christian advocacy that have specifically been examined have identified the issues that must be addressed for the church to perform its advocacy ministry effectively. The analysis of the available information point to the fact that the church must pay attention to niche management, capacity building of church leaders, enhancing public theology, creation of platforms for reflections, attacks on voices of wisdom, and the attention to the role of the non-clergy in the advocacy ministry for its effective and eminent Christian advocacy ministry.

\section{ABOUT AUTHOR}

Kwabena Opuni-Frimpong ( $\mathrm{PhD}$ ), Lecturer in African Christianity, Department of Religious Studies, Kwame Nkrumah University of Science and Technology, Kumasi - Ghana.

\section{BIBLIOGRAPHY}

Abuom, Agnes R.M. Report of Christian Council of Ghana on Organization Development Assessment July, 2005 .

Adarkwa, Kwasi Kwafo. Report on Christian Council of Ghana Strategic Plan 2014-2024, April 2024.

Anquandah, James. Agenda Extraordinaire: 80 years of the Christian Council of Ghana 1929-2009. Accra: Asempa Publishers 2009.

Asante Emmanuel. Theology and Society in Context: A Theologist's Reflections on Selected Topics. Accra: Sonlife Press, 2014.

Aryee, Joseph R.A., Leadership and the Ghanaian State Today: Reflections and Perspectives. Accra: Checkpoint, 2017.

Bediako, Kwame. Theology and Identity: The Impact of Culture Upon Christian Thought in the Second Century and Modern Africa. Oxford: Regnum Books 1992.

Communique on National Issues by the Christian Council of Ghana adopted at the Joint Heads of Churches and Organizations and Executive Meeting of the Christian Council of Ghana held at its Secretariat on December 17, 2013.

Communique on National issues by the Christian Council of Ghana adopted at the Joint Heads of Churches/ Organizations and Executive Committee Meeting of the Christian Council of Ghana held at its Secretariat on December 17, 2013.

Joint communique of the Christian Council of Ghana and the Ghana Pentecostal and Charismatic Council, issued in Accra on June 8, 2016.

Joint Press Statement by the Christian Council of Ghana and the Ghana Catholic Bishops' Conference Issued in Accra on May 18, 2016.

Communique issued by the Presbyterian Church of Ghana (PCG) at the end of its $19^{\text {th }}$ General Assembly at Abetifi-Kwahu in the Eastern Region of Ghana from $16^{\text {th }}-22^{\text {nd }}$ August, 2019.

Debrunner Hans W. A History of Christianity in Ghana. Accra: Waterville Publishing House 1967.

Essah, Kwame AS. Address presented as the Resident Advisor of Family Health International on the occasion of HIV/AIDS programme launch by the Presbyterian Church of Ghana at the Covenant Congregation Dzorwulu on Friday February 23, 2001.

Facing AIDS, the Challenge, the Churches' Response: A World Council of Churches Study Document. Geneva: WCC Publications, 2001.

Gifford, Paul. Ghana's New Christianity. Indianapolis: Indiana University Press 2004.

Gutierrez, Gustavo. A Theology of Liberation. New York: Orbis Books 1988.

Gyampo, R.E. The Church and Ghana's Drive Towards Democratic Consolidation and Maturity. Journal of 
Political Science Pub Aff3:161. 2015.

Karel, T. August. The Quest for Being Public Church, The South African Challenge to the Moravian Church in Context 1737-2004. Bellville: The Print-Man 2009.

Kim, Sebastian. Theology in the Public Sphere: Public Theology as a Catalyst for Open Debate. London:

SCM Press 2011.

Kwamena-Poh, M. A. Vision \& Achievement. Accra: Waterville Publishing House, 2011.

Kudadjie, JN and Aboagye -Mensah, RK. Christian Social Ethics Accra: Asempa Publishers, 1992.

Mante, JOY and Aboagye-Dankwa D. Presbyterian Church of Ghana, Synod Decisions and the Rationale behind the decisions (1975-200), (Accra: Adwinsa Publications, 2014).

Noel, Smith. The Presbytery Church of Ghana 1835-1960 Accra: Ghana Universities Press 1966.

Opuni-Frimpong, K. Christian Ministry of Advocacy. Accra: Sonlife Press 2015.

Presbyterian Church of Ghana. Report on HIV/AIDS/STD Education Programme for the Youth 2002.

Presbyterian Church of Ghana. Pastoral Policy on HIV/AIDS February 2002.

Presbyterian Church of Ghana, Manual of Order. Accra: Waterville Publishing House, 2017.

Rattray, R. S., Religion and Art in Ashanti. London: Oxford University Press, 1927.

Schweizer, Peter A. Survivors on the Gold Coast. Accra: Smartline Publishing 2000.

Stott, John. Issues Facing Christianity Today. London: Marshall Pickering 2006.

Tveit, Olav, Fykse. The Role of Religion in Sustainable Development and Peace. Berlin World Council of Churches. February 17-18, 2016.

Walls, Andrew. The Missionary Movement in Christian History. New York: Orbis Books, 1996.

Yeboah, Kwaku. Address presented as the Programme Manager, National AIDS Control Programme on the occasion of HIV/AIDS programme Launch by the Presbyterian Church of Ghana at the Covenant Congregation Dzorwulu on Friday February 23, 2001. 